\title{
Faktor-Faktor yang Mempengaruhi Pengungkapan Kebijakan Metode Transfer Pricing dalam Laporan Keuangan
}

\author{
Hani Werdi Apriyanti ${ }^{1}$ \\ Devi Permatasari² \\ Khoirul Fuad ${ }^{3}$ \\ Universitas Islam Sultan Agung \\ 'hani.apriyanti@unissula.ac.id \\ ²devi_p@unissula.ac.id \\ ${ }^{3}$ khoirulfuad.@unissula.ac.id
}

\begin{abstract}
ABSTRAK
Penelitian ini difokuskan pada isu transfer pricing, terutama masalah pengungkapan kebijakan metode transfer pricing di dalam laporan keuangan. Pernyataan Standar Akuntansi Keuangan (PSAK) No.7 Revisi 2010 mensyaratkan pengungkapan transaksi dengan pihak berelasi, transaksi dan saldo, termasuk komitmen, dalam laporan keuangan induk perusahaan terkonsolidasi dan terpisah, dan juga berlaku untuk laporan keuangan individu. Penelitian ini bertujuan untuk meneliti apakah pengungkapan kebijakan atas metode transfer pricing dihubungkan dengan karakteristik perusahaan, yaitu ukuran perusahaan (Size), dan struktur tata kelola perusahaan yaitu persentase komisaris independen, dan struktur kepemilikan. Sampel dalam penelitian ini ditentukan dengan metode perposive sampiling. Terdapat 90 perusahaan manufaktur yang memenuhi kriteria dalam penelitian ini. Metode statistik yang digunakan dalam penelitian ini adalah analisis regresi berganda. Berdasarkan hasil uji, terbukti bahwa ukuran perusahaan dan kepemilikan institusional tidak berpengaruh terhadap pengungkapan metode transfer pricing, sedangkan komisaris independen berpengaruh positif signifikan terhadap pengungkapan metode transfer pricing. Berdasarkan hasil penelitian ini, pemerintah, regulator, maupun pemilik perusahaan dapat menggunakan komisaris independen dalam melakukan pengawasan terkait dengan pengungkapan transaksi transfer pricing.
\end{abstract}

Kata Kunci : Transfer Pricing, ukuran perusahaan, komisaris independen, struktur kepemilikan

\section{ABSTRACT}

This research is focused on the issue of transfer pricing, especially the transfer pricing disclosure policy in the financial statements. Statement of Financial Accounting Standards (PSAK) No.7 Revised 2010 requires disclosure of transactions with related parties, transactions and balances, including commitments, in the consolidated and separate financial statements of the parent company, and also applies to individual financial statements. This study aims to examine whether the transfer pricing method disclosure policy is related to company characteristics, namely the size of the company (Size), and the structure of corporate governance namely the percentage of independent directors, and ownership structure. The sample in this study was determined by Perposive Sampiling method. There 
are 90 manufacturing companies that meet the criteria in this study. The statistical method used in this study is multiple regression analysis. Based on the test results, showed that company size and institutional ownership have no effect on the disclosure of the transfer pricing method, while the independent commissioner has a significant positive effect on the disclosure of the transfer pricing method. Based on the result, regulator, government and company needs to improve the independent commissioner percentage to encouredge the transfer pricing disclosure.

Keywords: Transfer Pricing, company size, independent commissioner, ownership structure

\section{PENDAHULUAN}

Transfer Pricing merupakan salah satu isu yang cukup menarik dan penting untuk diteliti. Transfer pricing berkaitan dengan transaksi yang dilakukan oleh perusahaan dengan pihak berelasi untuk berbagai kepentingan, salah satunya adalah kepentingan perpajakan. Berdasdarkan data Organization for Economic Cooperation and Development (OECD) transaksi perdagangan yang dilakukan oleh perusahaan multinasional, $60 \%$ dari transaksi perdagangan dan keuangan yang dilakukan antar lintas negara, terjadi di Indonesia. Isu transfer pricing berkaitan dengan kepentingan pajak perusahaan. Oleh karena itu, Tahun 2007 Dirjen Pajak melakukan berbagai upaya untuk menangani masalah transfer pricing dengan membentuk satuan khusus transfer pricing, mengadakan pelatihan pengetahuan pengetahuan transfer pricing bagi pemeriksa pajak, dan penempatan intel di beberapa negara tax heaven country .

Aktivitas perencanaan pajak yang dilakukan oleh perusahaan melalui skema Transfer pricing, sangat berpengaruh terhadap penerimaan pajak negara. Potensi kerugian negara akibat transfer pricing sebesar 1.300 Triliun Rupiah. Isu transfer pricing merupakan isu yang cutup punting dibandingkan dengan isu pajak yang lainya. Berdasarkan survey E\&Y $74 \%$ responden meyakini transfer pricing merupakan hal yang sangat penting bagi perusahaan, $65 \%$ responden menyatakan bahwa dokumentasi transfer pricing penting . Hasil survey ini membuktikan bahwa isu transfer pricing adalah isu yang penting baik bagi perusahaan sebagai wajib pajak maupun bagi pemerintah.

Penelitian ini difokuskan pada isu transfer pricing, yaitu pengungkapan kebijakan metode transfer pricing di dalam laporan keuangan. Pernyataan Standar Akuntansi Keuangan (PSAK) No.7 Revisi 2010 mengharuskan adanya pengungkapan transaksi dengan pihak berelasi, terkait transaksi dan saldo, komitmen, baik dalam laporan keuangan induk perusahaan terkonsolidasi maupun terpisah, serta berlaku untuk laporan keuangan individu. Dalam PSAK 7 tersebut tidak disebutkan secara eksplisit terkait kewajiban perusahaan dalamn mengungkapkan berbagai macam jenis transaksi secara detail terkait dengan pihak berelasi, termasuk metode transfer pricing di dalam laporan keuangan. Keputusan manajer untuk mengungkapkan kebijakan metode transfer pricing dalam laporan keuangan bersifat sukarela (voluntary), yaitu pengungkapan informasi yang dilakukan oleh perusahaan di luar pengungkapan yang diharuskan oleh aturan pasar modal dan telah melebihi tingkat persyaratan minimal yang ditetapkan oleh pasar modal (Nuswandari, 2009).

Perusahaan mengungkapkan informasi, baik pengungkapan langsung maupun pengungkapan tidak langsung untuk mengurangi asimetri informasi antara perusahaan dengan calon investor di pasar modal. Selain itu, pengungkapan informasi dilakukan untuk mengurangi tindakan menyimpang yang dapat 
menyamakan persepsi nilai saham perusahaan antara perusahaan, pasar, dan calor investor (Nuswandari, 2009). Dengan pengungkapan Penuh (di atas pengungkapan wajib yang disyaratkan pasar modal), pengguna laporan keuangan memiliki informasi yang lebih lengkap untuk memahami kegiatan bisnis atau operasional perusahaan. Pengungkapan sukarela (voluntary disclosre) dapat menaikkan tingkat transparansi laporan keuangan sebagai gambaran kondisi perusahaan yang sesungguhnya (Kurniawati \& Yaya, 2017). Tingkat pengungkapan laporan keuangan merupakan informasi dalam laporan keuangan maupun komunikasi pelengkap yang mencakup catatan kaki, peristiwa setelah pelaporan, analisis manajemen terkait kegiatan operasi masa datang, financial forecase, dan operasi, serta laporan keuangan tambahan (Kurniawati \& Yaya, 2017). Menurut (Healy, 1999) peningkatan dalam tingkat pengungkapan berhubungan dengan peningkatan dalam return saham perusahaan, institutional ownership, analyst forecast, dan likuiditas saham. Tingkat pengungkapan sukarela dapat dikaitkan dengan biaya modal serta utang yang lebih rendah (Lo, 2011). Manajer dapat memilih, untuk mengungkapkan atau tidak mengungkapkan secara sukarela informasi, hal ini karena adanya biaya pengungkapan (E.Verrecchia, 1983), (R.Graham, Harvey, \& Rajgopal, 2005), (Suijs, 2005). Untuk melakukan pengungkapan sukarela, perusahaan memerlukan biaya yang semakin tinggi untuk untuk menyediakan informasi tambahan tersebut (Nuswandari, 2009).

Transfer pricing merupakan harga yang diperhitungkan untuk kepentingan pengendalian manajemen atas transfer barang maupun jasa antar divisi dalam satu perusahaan, atau antar perusahaan yang memiliki relasi (Simamora, 1999). Perusahaan tidak memiliki kewajiban untuk mengungkapkan informasi terkait transaksi yang dilakukan dengna pihak berelasi dalam laporan keuangan. Pengungkapan yang diwajibkan terkait transfer pricing hanya berkaitan dengan pendokumentasian yang diwajibkan oleh ketentuan perpajakan. Peraturan Pemerintah No.28 Tahun 2007 Pasal 16 ayat (2) mengharuskan Wajib Pajak untuk menyimpan dokumen transaksi dengan para pihak yang mempunyai hubungan istimewa, dan atau informasi tambahan yang menjadi dasar dalam pembukuan atau pencatatan. Kewajiban ini berkaian dengan pemenuhan prinsip kewajaran dan kelaziman usaha atas transaksi perusahaan dengan pihak yang memiliki hubungan istimewa. Tidak ada kewajiban untuk mengungkapkan di dalam laporan keuangan. Akan ada kecenderungan penyimpangan terhadap harga yang sudah disepakati, dan rekayasa secara sistemaris untuk mengurangi laba perusahaan (Simamora, 1999). Akan ada kecenderungan penyimpangan terhadap harga yang sudah disepakati, dan rekayasa secara sistemaris untuk mengurangi laba perusahaan. Dengan adanya hal tersebut, menjadi hal yang wajar jika perusahaan tidak mengungkapkan metode penentuan harga transfer di dalam laporan keuangan.

Keputusan penentuan kesepakatan harga transfer antar divisi dapat menimbulkan masalah antara unit pembeli dan unit penjual. Hal ini terjadi karena penentuan harga transfer akan berpengaruh terhadap pengukuran laba baik unit pembeli maupun penjual. Jika harga transfer tinggi, maka akan merugikan unit pembeli, dan jika harga transfer terlalu rendah akan merugikan unit penjual. Oleh karena itu, penentuan harga transfer merupakan persoalan yang sangat penting bagi perusahaan yang terdiri dari unit-unit yang melakukan transksi barang atau jasa. Bagi perusahaan multinasional, harga transfer seringkali digunakan untuk motif dalam melakukan penghindaran pajak (Sikka, 2010). Penentuan metode transfer pricing untuk 
penghindaran pajak sebagian besar tidak terlihat oleh publik dan sangat sulit dan mahal bagi pemerintah untuk mendeteksi hal tersebut (Sikka, 2010). Pengungkapan informasi, termasuk metode transfer pricing dapat meningkatkan biaya keagenan, baik biaya pengungkapan, maupaun biaya politik untuk penyelesaian masalah agensi. Manajemen akan mensyaratkan peningkatan kompensasi, ketika peningkatan pengungkapan sukarela dinaikkan (Nuswandari, 2009). Selain itu, peningkatan pengungkapan informasi yang bernilai akan dapat menguntungkan perusahaan kompetitor.

Penelitian sebelumya tentang faktor-faktor yang mempengaruhi pengungkapan secara sukarela transfer pricing telah dilakukan oleh Lo (2011) dengan hasil penelitian tersebut menyatakan bahwa perusahaan yang membuat pengungkapan secara sukarela metode transfer pricing secara negatif dihubungkan dengan tingkat earning manajemen yang lebih tinggi, incentive, dan berhubungan positif dengan persentase independen director yang lebih tinggi, dan kepemilikan pemerintah. Penelitian ini hanya menjelaskan bahwa earning management beserta insentifnya, komposisi dewan direksi, dan struktur kepemilikan secara signifikan mempengaruhi keputusan pengungkapan secara sukarela bagi manajer. Secara lebih mendalam penelitian tersebut menyarankan bahwa untuk meningkatkan pengungkapan secara sukarela, sebaiknya digunakan kompensasi yang dikaitkan dengan harga saham untuk memotivasi manajer, dan untuk menghindari skandal keuangan di masa datang, dengan meningkatkan persentase independen director dan mendorong institusional investor berinvestasi di perusahaan mereka.

Penelitian ini bertujuan untuk memeriksa apakah pengungkapan kebijakan atas metode transfer pricing dihubungkan dengan karakteristik perusahaan, yaitu ukuran perusahaan (size) dan struktur tata kelola perusahaan yaitu persentase komisaris independen, dan struktur kepemilikan berupa kepemilikan institutional. Perusahaan dengan ukuran perusahaan yang lebih besar yang diukur dengan total aset yang dimiliki akan lebih besar kemungkinanya untuk mengungkapkan informasi atas metode transfer pricing. Perusahaan yang besar memiliki sumber daya yang cukup untuk melakukan pengungkapan, sehingga masalah biaya pengungkapan tidak lagi menjadi masalah bagi perusahaan dengan ukuran yang besar. Oleh karena perusahaan yang besar dimungkinkan tidak akan menghindari biaya politik yang akan timbul akibat adanya pengungkapan transfer pricing. Perusahaan berukuran besar berpandangan bahwa manfaat atas pengungkapan metode transfer pricing lebih besar dibandingkan dengan biaya yang ditimbulkan atas pengungkapan tersebut, sehingga perusahaan termotivasi untuk melakukan pengungkapan.

Komisaris independen dan pemegang saham institutional dapat membantu dalam memonitor keputusan manajemen dan mendorong manajemen untuk mengungkapkan metode transfer pricing (Lo,2011). Sebaliknya manajemen akan lebih kecil kemungkinanya untuk mengungkapkan informasi atas metode transfer pricing jika terdapat manipulasi laba dengan memanipulasi harga transfer atas transaksi dengan pihak berelasi dan adanya antisipasi konsekuensi negatif (biaya pengungkapan) atas pengungkapan informasi tersebut kepada pemegang saham. Perusahaan yang memiliki persentase komisaris independen tinggi memiliki kemungkinan yang besar dalam melakukan pengungkapan informasi keuangan dan non keuangan secara lebih rinci atas transaksi dengan pihak berelasi.

Teori keagenan menyatakan bahwa struktur kepemilikan yang menyebar dapat mendorong 
pengungkapan informasi yang lebih banyak untuk memperkecil biaya keagenan (Almilia, 2008). Menurut Almilia (2008),Perusahaan yang kepemilikan sahamnya menyebar, memiliki kemungkinan yang lebih besar terjadi konflik keagenan. K. Chaua dan J.Gray (2002), Eng dan Mak (2003) membuktikan bahwa ownership structure berpengaruh terhadap pengungkapan informasi perusahaan.

Pengungkapan metode transfer pricing merupakan keputusan manajemen yang bersifat voluntary (sukarela) di Indonesia. Manajer dapat memilih untuk mengungkapkan atau tidak mengungkapkan metode transfer pricing dalam catatan atas laporan keuangan. Tujuan penelitian ini adalah menguji pengaruh ukuran (company size) perusahaan terhadap pengungkapan kebijakan metode transfer pricing,, pengaruh Persentase Komisaris Independen terhadap Pengungkapan sukarela atas kebijakan metode transfer pricing, dan pengaruh kepemilikan institutional terhadap Pengungkapan sukarela kebijakan metode transfer pricing .

\section{TELAAH LITERATUR DAN PENGEMBANGAN HIPOTESIS}

\section{Teori Keagenan ( Agency Theory)}

Jensen \& Meckling (1976) mendefinisikan agency theory atau teori keagenan sebagai hubungan kontrak antara prinsipal (pemilik perusahaan) dan agen (manajemen perusahaan). Dalam hubungan keagenan terdapat kontrak antara principal dengan agen, yaitu prinsipal mendelegasikan tugas pengelolaan perusahaan kepada agen. Hubungan kontrak antara prinsipal dan agen dapat menimbulkan konflik kepentingan. Sesuai dengan teori agency, manager (agen) dipersepsikan sebagai manusia ekonomi (socio ekonomi) yang berusaha meningkatkan kemakmuran bagi kepentingan individu sebagai seorang manajer.

Agen sebagai pengelola perusahaan memiliki informasi yang Penuh terhadap kondisi perusahaan baik informasi internal, maupun perkiraan prospek perusahaan pada masa yang akan datang. Agen atau manager bertanggung jawab atas pengelolaan perusahaan dengan memberikan informasi tentang kondisi perusahaan kepada pemilik atau prinsipal. Perbedaan kepentingan antara prinsipal dan agen dapat memicu tindakan menyimpang agen dengan melakukan manipulasi laporan keuangan. Tindakan menyimpang ini dapat menyebabkan asimetri informasi (asymmetry information), salah satu caranya dilakukan melalui manajemen laba agar laporan keuangan terlihat bagus (Richardson, 1998). Untuk mengurangi perbedaan informasi antara agen sebagai pengelola perusahaan dan principal sebagai pemilik, maka manajer secara sukarela mengungkapkan informasi (Wagenhofer, 1990 dalam Lo, 2011).

Menurut Eisenhardt (1989) konflik agensi dapat terjadi jika pemilik tidak dapat mengontrol perilaku agen. Hal ini dapat menimbulkan masalah keagenan serta adverse selection yang dapat berdampak pada meningkatnya biaya keagenan. Lebih luas lagi, hal ini akan berdampak juga terhadap perilku investor dalam mengambil keputusan. Menurut Wagenhofer (1990) dalam Lo (2011), selain untuk mengurangi asimetri informasi, pengungkapan secara sukarela juga dilakukan untuk memimalisir adverse selection yang dilakukan oleh investor. Terlebih, pengungkapan informasi tambahan dapat membantu calon investor untuk membuat keputusan membeli atau menjual yang lebih tepat (Nuswandari 2009). Akan tetapi, pengungkapan informasi tambahan ini dapat meningkatkan masalah keagenan. Peningkatan luas informasi, akan berakibat pada naiknya kompensasi bagi manajemen (Nuswandari, 2009). Manajemen akan mempersyaratkan kompensasi 
yang lebih tinggi untuk tingkat pengungkapan yang lebih tinggi.

Teori keagenan menjelaskan, bahwa masalah agensi dapat terjadi ketika manajer (agen) melakukan tindakan yang dapat meningakatkan kemakmuran, melalui manajemen laba. Manajemen laba dilakukan melalui pemilihan kebijakan akuntansi dari suatu standard tertentu atau metode akuntansi tertentu untuk memaksimalkan kesejahteraan manajer (Kurniawati \& Yaya, 2017). Manajer terdorong melakukan manajemen laba dengan rekayasa kinerja operasi perusahaan yang sesungguhnya (Sugiri, 2005). Manager dapat melakukan manajemen laba dengan penentuan pendapatan yang dikaitkan dengan pengakuan beban yang dapat berpengaruh terhadap laba akuntansi. Hal ini dilakukan karena laba akuntansi yang dilaporkan menjadi dasar dalam penentuan kompensasi manajemen. Manajemen laba yang dilakukan untuk mempengaruhi penghasilan perusahaan dapat dilakukan melalui transaksi dengan pihak berelasi secara khusus melalui penentuan metode transfer pricing.

Menurut teori keagenan, konflik agensi yang terjadi antara manager dan pemilik dapat akan menimbulkan biaya keagenan untuk penyelesaian konflik tersebut. Tindakan oportunistik berupa earning management (manajemen laba) oleh manajer dapat menimbulkan biaya keagenan (A.Zahra, :.Priem, \& A.Rasheed, 2005), (Xie, Davidson, \& Dadalt, 2003). Menurut Nuswandari (2009), konflik keagenan akan semakin besar terjadi pada perusahaan yang memiliki kepemilikan saham yang menyebar. Hal ini berarti semakin tinggi konflik keagenan, semakin tinggi biaya keagenan yang akan timbul. Perusahaan dengan struktur kepemilikan yang menyebar akan meningakatkan pengungkapan informasi untuk meminimalkan biaya keagenan (Nuswandari, 2009). Hal ini berarti, perusahaan yang memiiliki struktur kepemilikan menyebar, akan lebih besar kemungkinanya untuk melakukan pengungkapan informasi lebih tinggi, termasuk kebijakan metode transfer pricing di dalam laporan keuanganya.

Masalah agency muncul karena manajer yang mengelola perusahaan memiliki kepentingan yang berbeda (memaksimalkan kemakmuran pribadi) dengan prinsipal. Selain itu, prinsipal merupakan pihak yang berada di luar perusahaan atau entitas di luar perusahaan yang memiliki informasi terbatas atas perusahaan. Oleh karena itu, prinsipal harus melakukan pengendalian untuk memastikan tindakan manajer agar sesuai dengan kepentingan pemilik. Manajer harus diawasi oleh pihak lain, yaitu dewan komisaris, melalui komisaris independen. Komisaris independen merupakan mekanisme internal dalam corporate governance yang berfungsi melakukan pengawasan. Menurut Byrd dan Hickman dalam Lo ( 2011) salah satu mekanisme internal yang panting dalam tata kelola perusahaan (corporate governance) adalah komisaris independen. Komisaris Independen merupakan pihak independen yang dapat berperan dalam mengawasi aktivitas perusahaan termasuk kebijakan manajer dalam pengelolaan perusahaan.

\section{Transaksi dan Pengungkapan Pihak Berelasi}

Pernyataan Standar Akuntansi Keuangan (PSAK) No.7 memyebutkan bahwa laporan keuangan harus mengungkapkan transaksi dan saldo dengan pihak -pihak yang mempunyai hubungan istimewa, termasuk komitmen dalam laporan keuangan kosolidasian dan laporan tersendiri entitas induk. Transaksi dengan pihak yang memiliki hubungan istimewa merupakan transaksi yang dilakukan perusahaan dengan perusahaan 
dengan hubungan kepemilikan, pemilik perseorangan atau karyawan dengan pengaruh signifikan, anggota keluarga perorangan, dan perusahaan yang dimiliki secara substansial oleh perorangan tersebut.

PSAK 07 tersebut telah digantikan dengan PSAK 7 (revisi 2010), dengan penggantian istilah pihak yang mempunyai hubungan istimewa dengan pihak yang berelasi. PSAK ini mengacu pada strandar akuntansi internasional (International Accounting Standard) No.24 tentang "Related Party Disclosure". Dalam Penelitian ini transaksi dengan pihak berelasi selanjutnya disebut Related Party Transaction (RPT).

Related PartyTransaction (RPT) dapat dikaitkan dengan transaksi untukkepentingan oportunis perusahaan, terutama berkaitan dengan perencanaan pajak. Penelitian (Adolf A \& C.Means, 1932) dan (Jensen \& Meckling, 1976) membuktikan bahwa transaksi dengan pihak berelasi digunakan sebagai alat untuk mengambil kekayaan perusahaan. Related Party Transaction menunjukkan kecenderungan oportunis perusahaan, terutama untuk kepentingan pajak (TJ.Wong \& Jian, 2003). Tingkat penjualan dengan pihak berelasi, baik transaksi dengan pemegang saham pengendali maupun anggota lain dalam satu grup perusahaan akan cenderung tinggi jika perusahaan memiliki motivasi untuk melakukan managemen laba.

Related Party Transaction (RPT) menunjukkan kecenderungan oportunis (Gordon, 2004). Frekuensi Related Party Transaction (RPT) akan semakin berkurang jika perusahaan dapat menerapkan tata kelola perusahaan yang baik (orporate governance ). Penerapan mekanisme internal dalam corporate governance, yaitu dengan adanya persentase kepemilikan pihak luar, baik keemilikan pemerintah maupun institusi serta adanya komisaris independen diduga dapat menurunkan frekuensi transaksi dengan pihak berelasi. Kemungkinan tingginya Related Party Transaction (RPT) dihubungkan dengan rendahnya persentase jumlah komisaris independen terhadap jumlah dewan komisaris (Kohlbeck \& W.Mayhew, 2004). Penelitian Thomas (2011) menemukan bahwa Related Party Transaction (RPT) dilakukan sebagai salah metode untuk melakukan management laba .

\section{Transfer Pricing Disclosure}

Pengaturan dan analisis terhadap transfer pricing memainkan peranan penting dan berbeda di dalam pelaporan keuangan. Transfer Pricing dapat berdampak ke berbagai wilayah mulai dari restrukturisasi bisnis sampai pada valuation allowance. Transfer Pricing juga dapat menjadi relevan dalam laporan keuangan secara terpisah dan akuisisi akuntansi. Ketika menyiapkan laporan keuangan dan pengungkapan, perhatian harus diberikan terhadap hubungan penyebab dan dampak dari transfer pricing terhadap pre-tax dan income tax account.

Perusahaan harus menyadari kemungkinan dampak transfer pricing terhadap estimasi dan asersi akuntansi yang dapat menjamin pengungkapan dalam laporan keuangan. Pengungkapan catatan kaki pajak penghasilan (income tax footnote disclosure) dapat memuat diskusi tentang strategi transfer pricing yang berfungsi sebagai bukti objektif positif dalam mendorong realisasi aktiva pajak tangguhan perusahaan (Company's deffered tax asset). Peningkatan dan penurunan dalam tabel rekonsiliasi manfaat pajak yang tidak diketahui yang berkaitan dengan ketidakpastian transfer pricing harus dilaporkan secara ekslusif terkait manfaat hukum lainya.

Perusahaan yang terdaftar dalam pasar modal wajib mendiskusikan kondisi keuangan saat ini dan 
perubahan yang diharapkan dalam diskusi manajemen dan analisis kondisi keuangan dan hasil operasi. Pertimbangan tertentu terhadap dampak transfer pricing harus diberikan dalam diskusi ini, meliputi resiko dan ketidakpastian yang dihubungkan dengan kebijakan transfer pricing yang dapat mempengaruhi liukuiditas dan sumber daya modal.

Berdasarkan PSAK No 7 Revisi 2010, pengungkapan yang wajib adalah terkait dengan transaksi denga pihak istimewa, dan tidak secara khusus berkaitan dengan pengungkapan metode transfer pricing. Transfer Pricing Disclosure di dalam laporan keuangan merupakan pilihan manajemen sebagai voluntary disclosure untuk memperluas informasi bagi user. Panduan terkait Transfer Pricing Disclosure bagi perusahaan dapat diperloleh secara fleksibel oleh perusahaan, melalui beberapa konsultan pajak, seperti PWC, E \& Y.

\section{Ukuran Perusahaan}

Ukuran perusahaan dapat diproksikan dengan total aset yang dimiliki perusahaan. Ukuran perusahaan menjadi menjadi salah satu faktor yang mempengaruhi pengungkapan kebjakan metode transfer pricing perusahaan. Perusahaan dengan total aset yang besar, memiliki sumber daya yang besar untuk membiayai pengungkapan informasi keuangan. Selain itu, dengan sumber daya yang dimiliki, perusahaan tidak terkendala dalam mengeluarkan biaya keagenan yang dapat terjadi karena pengungkapan informasi transfer pricing. Semakin besar jumlah aset perusahaan maka semakin besar pula ukuran perusahaan tersebut, semakin besar kemungkinan melakukan pengungkapan kebijakan transfer pricing (Putri \& Nasir, 2006).

\section{Struktur Kepemilikan}

Struktur kepemilikan perusahan merupakan mekanisme internal dalam tata kelola perusahaan (Novitasari \& Indira, 2009).Struktur kepemilikan merupakan komposisi kepemilikan saham suatu perusahaan yang menjelaskan komitmen pemegang saham sebagai pemilik untuk mendanai kegiatan operasional perusahaan (Novitasari \& Indira, 2009). Menurut teori keagenan, semakin menyebar struktur kepemilikan perusahaan, semakin tinggi kemungkinan perusahaan melakukan pengungkapan informasi keuangna dan non keuangan untuk mengurangi biaya keagenan (Nuswandari, 2009).Struktur kepemilikan yang menyebar, yaitu kepemilikan institusional merupakan sarana untuk memonitor manajemen (Machmud \& D.Djakman, 2008). Pemilik institusional merupakan pemegang saham yang cenderung tersebar yang memungkinkan untuk mengawasi aktivitas manajemen. Sebagai pemilik institusional, meraka dapat mendorong manajemer untuk mengungkapkan informasi yang lebih lengkap dalam laporan keuangan. Pengungkapan ini dibutuhkan sebagai bentuk transparansi perusahaan kepada stakeholder, untuk menaikkan nilai perusahaan melalui mekanisme pasar modal yang akan mempengaruhi harga saham perusahaan (Brancato dan Gaughan, 1991 dalam (Fauzi, S.Mahoney, \& Rahman, 2007).

\section{Penelitian terdahulu}

Peneliti melakukan review atas hasil penelitian terdahulu untuk mengetahui isu-isu yang pernah dibahas berkaitan dengan transfer pricing. Dengan fenomena kebijakan transfer pricing di Indonesia, ada beberapa 
penelitian yang pernah dilakukan terkait transfer pricing. Peneliti berhasil mereview beberapa penelitian sebelumnya, dan satu diantaranya adalah penelitian dalam setting Indonesia. Penelitian sebelumnya terkait transfer pricing dipaparkan dalam tabel 1.

Tabel 1. Ringkasan Perbandingan Penelitian Terdahulu

\begin{tabular}{|c|c|c|c|c|}
\hline No & Peneliti (Tahun) & Judul & Variabel & Hasil Penelitian \\
\hline 1 & $\begin{array}{l}\text { (Boyns, Edward, \& } \\
\text { Emmanuel, 1999) }\end{array}$ & $\begin{array}{l}\text { Determinans of } \\
\text { the transfer pricing } \\
\text { change }\end{array}$ & - & $\begin{array}{l}\text { Perubahan dalam transfer } \\
\text { pricing dapat menimbulkan } \\
\text { kesempatan untuk memeriksa } \\
\text { penyebab diperlukanya } \\
\text { perubahan }\end{array}$ \\
\hline 2 & (F.Gox, 2000) & $\begin{array}{l}\text { Strategic Transfer } \\
\text { Pricing }\end{array}$ & - & $\begin{array}{l}\text { Jika metode transfer pricing } \\
\text { dapat diobservasi, perusahaan } \\
\text { pesaing cenderung akan } \\
\text { mengubah harga transfer } \\
\text { untuk dapat berkompetisi } \\
\text { dalam pasar }\end{array}$ \\
\hline 3 & $\begin{array}{l}\text { Lo } \\
(2011)\end{array}$ & $\begin{array}{l}\text { An empirical } \\
\text { study of valuntary } \\
\text { transfer pricing } \\
\text { disclosure in China }\end{array}$ & $\begin{array}{l}\text { Disclosed,Earning } \\
\text { Management, } \\
\text { Independen Directur, } \\
\text { Institutional } \\
\text { Ownership, I. } \\
\text { Goverment }\end{array}$ & $\begin{array}{l}\text { Earning management beserta } \\
\text { incentivenya, komposisi } \\
\text { dewan direksi, dan struktur } \\
\text { kepemilikan secara signifikan } \\
\text { mempengaruhi keputusan } \\
\text { pengungkapan secara sukarela } \\
\text { bagi manajer }\end{array}$ \\
\hline 4 & $\begin{array}{l}\text { Sikka } \\
(2010)\end{array}$ & $\begin{array}{l}\text { The Dark Side Of } \\
\text { Trnasfer Pricing } \\
\text { :It's Role in Tax } \\
\text { Avaoidance } \\
\text { and wealth } \\
\text { Retentiveness }\end{array}$ & - & $\begin{array}{l}\text { Transfer Pricing merupakan } \\
\text { teknik optimal untuk alokasi } \\
\text { cost dan revenue diantara } \\
\text { devisi }\end{array}$ \\
\hline 5 & $\begin{array}{l}\text { Eden } \\
(2011)\end{array}$ & $\begin{array}{l}\text { The Ethics Of } \\
\text { Transfer Pricing }\end{array}$ & - & $\begin{array}{l}\text { Manipulasi Transfer Pricing } \\
\text { (TPM) adalah keuntungan } \\
\text { internal perusahaan, TPM } \\
\text { dapat dijelaskan melalui } \\
\text { fraud Triangle (opportunity, } \\
\text { pressure, rationalization) }\end{array}$ \\
\hline 6 & $\begin{array}{c}\text { (Talha, Alam, \& } \\
\text { Sallehhuddin, 2005) }\end{array}$ & $\begin{array}{l}\text { Transfer Pricing } \\
\text { and Taxation } \\
\text { Implications } \\
\text { Disclosure in } \\
\text { Segmental } \\
\text { Reporting }\end{array}$ & - & $\begin{array}{l}\text { Laporan Transfer Pricing } \\
\text { diungkapkan dalam laporan } \\
\text { segmen, dan transfer pricing } \\
\text { disclosure merupakan } \\
\text { voluntary disclosure di } \\
\text { Malaysia }\end{array}$ \\
\hline
\end{tabular}

Sumber : Data diolah, 2018 


\begin{tabular}{|c|c|}
\hline Variabel Independen & Variabel Dependen \\
\hline $\begin{array}{l}\text { Ukuran perusahaan } \\
\text { Komisaris Independen } \\
\text { Stuktur Kepemilikan }\end{array}$ & $\begin{array}{l}\text { Pengungkapan Metode } \\
\text { Transfer Pricing (Transfer } \\
\text { Pricing Disclosure) }\end{array}$ \\
\hline
\end{tabular}

\section{Gambar 1.1 Kerangka Pemikiran teoritis}

\section{Pengembangan Hipotesis}

\section{Ukuran Perusahaan terhadap Pengungkapan Metode Transfer Pricing}

Semakin besar total aset perusahaan yang menggambarkan ukuran perusaan yang besar, semakin besar kemungkinan perusahaan mengungkapkan berbagai informasi untuk memperkecil asimetri informasi antara manajemen dan stakeholders. Perusahaan yang besar memiliki motivasi untuk meningaktkan kepercayaan stakeholders dengan memperkecil konflik keagenan dengan mengungkapkan informasi yang dilakukan dengan pihak yang bereleasi, termasuk kebijakan metode transfer pricing antar divisi di dalam perusahaan. Dalam meneliti apakah ukuran perusahaan berpengaruh terhadap pengungkapan metode transfer pricing, peneliti menggunakan teori keagenan (Agency Theory). Berdasarkan teori keagenan, dalam hubungan antara principal dan agent, dapat muncul konflik agensi yang terjadi ketika para manajer (agen) melakukan tindakan oportunis seperti manajemen laba untuk memaksimalkan kepentingan sendiri melalui transfer harga antara divisi penjual dan divisi pembeli dalam perusahaan (transfer pricing). Penelitian sebelumnya menyatakan bahwa manajemen laba yang salah satu motivasinya dilakukan untuk mempengaruhi penghasilan dapat dilakukan melalui transaksi dengan pihak yang berelasi, secara khusus melalui penentuan metode transfer pricing.

Dari uraian di atas, maka hipotesis pertama dalam penelitian ini adalah:

H1: Ukuran perusahaan mempengaruhi pengungkaan metode transfer pricing dalam laporan keuangan

\section{Komisaris Independen terhadap Pengungkapan Sukarela Metode Transfer Pricing}

Manajer sebagai agen dari pemegang saham, mengelola perusahaan sesuai dengan kepentingannya sendiri (Jensen \& Meckling, 1976). Lebih lanjut menurut Jensen \& Meckling (1967) dapat muncul masalah karena pemisahan kepemilikan dan pengendalian. Teori agensi menyarankan bahwa keputusan manajer harus dimonitor untuk memastikan bahwa mereka bertindak sesuai dengan kepentingan pemegang saham. Untuk memonitor manajer secara tepat, dewan direksi dipercaya oleh pemegang saham, bekerja memastikan bahwa kebiajakan manajer berada dalam kepentingan pemegang sham dan bahwa laporan keuangan menggambarkan posisi keuangan perusahaan yang benar. Peranan tata kelola perusahaan dimainkan oleh Komisaris Independen (Byrd dan Hickman, 1996 dalam Lo, 2011).

Untuk memastikan bahwa laporan keuangan menggambarkan posisi keuangan yang benar, komisaris 
independen bertanggung jawab terhadap transparansi informasi perusahaan (Ajinkya, 2005). Dengan demikian, peningkatan jumlah komisaris independen dihubungkan dengan tingginya kualitas pengungkapan atau tingginya pengungkapan sukarela. Penelitian sebelumnya, menunjukkan hubungan antara komisaris independen dan tingkat pengungkapan. Semakin tinggi proporsi komisaris independen maka semakin tinggi tingkat pengungkapan (Karamanou \& Vafeas, 2005). Berdasarkan uraian tersebut, peneliti mengajukan hipotesis bahwa perusahaan dengan persentase komisaris independen yang lebih tinggi di dalam dewan komisaris akan lebih besar kemungkinanya untuk mengungkapkan metode transfer pricing dengan pihak yang memiliki hubungan istimewa di dalam laporan keuangan.

H2: Perusahaan dengan persentase komisaris independen yang tinggi akan semakin besar kemungkinanya mengungkapkan metode transfer pricing dalam laporan keuangan.

\section{Struktur Kepemilikan terhadap Pengungkapan Sukarela Metode Transfer Pricing}

Berdasarkan teori keagenan, dalam hubungan antara agen dan principal dapat muncul konflik keagenan, sehingga akan menimbulkan biaya keagenan. Tindakan oportunistik (manajemen laba) yang dilakukan oleh manajemen juga dapat menimbulkan biaya keagenan (A.Zahra, :.Priem, \& A.Rasheed, 2005), (Xie, Davidson, \& Dadalt, 2003). Teori keagenan menyatakan bahwa semakin menyebar struktur kepemilikan saham perusahaan, perusahaan diharapkan akan mengungkapkan informasi lebih banyak untuk mengurangi biaya keagenan

Menurut Nuswandari (2009) konflik keagenan akan semakin besar bagi perusahaan yang memiliki penyebaran kepemilikan saham perusahaan. Hal ini berarti dengan dengan konflik keagenan yang semakin besar maka biaya keagenan yang akan timbul juga semakin besar. Untuk mengurangi biaya keagenan tersebut, pada perusahaan dengan struktur kepemilikan yang menyebar, maka perusahaan akan mengungkapkan informasi lebih banyak (Nuswandari, 2009). Hal ini berarti, pada perusahaan yang memiiliki struktur kepemilikan menyebar, akan lebih besar kemungkinanya untuk mengungkapkan informasi lebih banyak, termasuk kebijakan metode transfer pricing di dalam laporan keuangan.

Struktur kepemilikan yang menyebar, yaitu kepemilikan institusional merupakan sarana untuk memonitor manajemen (Machmud \& D.Djakman, 2008). Kepemilikan institusional merupakan pemegang saham tersebar sehingga merupakan sarana yang tepat untuk memonitor manajemen. Investor institusional dapat meminta manajemen perusahaan untuk mengungkapkan informasi yang diperlukan dalam laporan tahunannya sebagai transparansi kepada stakeholder. Perusahaan dengan tingkat kepemilikan institusional yang tinggi maka tingkat pengungkapanya juga akan semakin tinggi (Healy, 1999). Uraian tersebut mendukung hipotesis di bawah ini:

H3 : Perusahaan dengan tingkat kepemilikan institutioanal yang tinggi akan lebih tinggi kemungkinanya untuk mengungkapkan metode transfer pricing dalam laporan keuangan

\section{METODOLOGI PENELITIAN}

Penelitian ini merupakan penelitian kuantitatif deskriptif yang menjelaskan pengaruh antara variabel Independen dengan variabel dependen dalam penelitian. Populasi dalam penelitian ini adalah seluruh 
perusahaan yang terdaftar di Bursa Efek Indonesia (BEI) periode 2015 - 2017. Sampel penelitian ini adalah perusahaan industri non keuangan yang terdaftar di Bursa Efek Indonesia (BEI) tahun 2015 - 2017. Penentuan sampel perusahaan non keuangan dipilih karena perusahaan non keuangan diindikasikan melakukan transaksi dengan pihak berelasi yang berkaitan dengan transfer harga antar divisi dalam satu perusahaan atau di luar perusahaan. Penentuan sampel menggunakan metode Purposive sampling, dengan kriteria sampel Perusahaan yang menerbitkan laporan tahunan lengkap untuk masing masing tahun dan memiliki data yang lengkap terkait dengan variabel yang digunakan dalam penelitian.

Variabel dependen dalam penelitian ini adalah pengungkapan metode transfer pricing (DISCLOSED), sedang variabel independen dalam penelitian ini adalah ukuran perusahaan, Persentase dewan komisaris independen, dan struktur kepemilikan (kepemilikan institutional). Teknik Analisis Statistika yang digunakan dalam penelitian ini adalah stratistik deskriptif dan regresi linier berganda. Dalam melakukan analisis regresi berganda, terlebih dahulu dilakukan pengujian asumsi klasik agar memenuhi sifat estimasi regresi bersifat BLUES (Best Linier Unbiased Estimator).

$\begin{array}{ll}\begin{array}{l}\text { Persamaan Regresi } \\ \text { DISCLOSED }=a 0+a 1 \text { SIZE + a 2KOM-IND + a } 3 \\ \text { Keterangan }\end{array} & \\ \text { DISCLOSED } & =\text { Pengungkapan Metode Transfer Pricing } \\ \text { a0 } & =\text { Konstanta } \\ \text { a1- } a 4 & =\text { Koefisien } \\ \text { SIZE } & =\text { Ukuran Perusahaan } \\ \text { KOM-IND } & =\text { Komisaris Independen } \\ \text { INSTITUTE } & =\text { Kepemilikan Institusional }\end{array}$

\section{HASIL DAN PEMBAHASAN}

\section{Deskripsi Objek Penelitian}

Perusahaan manufaktur yang terdaftar di BEl pada 2015-2017 berjumlah 460, 396 perusahaan merupakan perusahaan sektor non keuangan, dan 30 perusahaan memenuhi kriteria pengambilan sampel. Sampel yang digunakan dalam penelitian ini berjumlah 90 perusahaan.

\section{Deskripsi Variabel Penelitian}

Variabel dependen dalam penelitian ini adalah pengungkapan kebijakan metode transfer pricing dan merupakan variabel dummy, yang diberi skor 1 jika perusahaan mengungkapkan kebijakan metode transfer pricing, dan diberi skor nol jika prusahaan tidak mengungkapkan kebijakan metode transfer pricing. Rata-rata perusahaan sampel adalah perusahaan dengan kepemilikan institusional di atas 50\%. Rata-rata Persentase komisaris independen perusahaan sampel. Sebesar 33,97 persen. Perusahaan sampel memiliki ukuran 
perusahaan yang beragam. Perusahaan sampel memiliki ukuran perusahaan yang beragam yang ditunjukkan dengan nilai terendah 11,6 sampai nilai tertinggi sebesar 19,5. Dengan rata-rata 14,2. Rata-rata pengungkapan kebijakan metode transfer pricing adalah 0,73. Hal ini menunjukkan bahwa tingkat pengungkapan kebiajakn metode transfer pricing dalam perusahaan sampel cukup tinggi. Kepemilikan institutional memiliki rata-rata 0,61 atau sekitar $61 \%$. Nilai rata-rata tersebut menunjukkan bahwa sebagian besar perusahaan memiliki konsentrasi kepemilikan institutional yang hampir mencapai nilai konsentrasi 50\% (setengah dari kepemilikan perusahaan) dan hal ini menunjukkan bahwa terdapat hak pengendalian yang kuat dengan tingginya konsentrasi kepemilikan tersebut. Variabel komisaris independen memiliki rata-rata 0,3397. Hal ini menunjukkan bahwa persentase komisaris independen dalam dewan komisaris pada perusahaan sampel sudah memenuhi batas minimal 30\% sesusai peraturan Otoritas Jasa Keuangan.

Tabel 2. Descriptive Statitics

\begin{tabular}{lrrr}
\hline & Mean & Std. Deviation & $\mathrm{N}$ \\
\hline RPT-D & .73 & .445 & 90 \\
\hline Size & 14.23187702 & 1.978496452 & 90 \\
\hline Leverage & .76792288 & 2.220360333 & 90 \\
\hline Profitabilitas & .01907003 & .104001713 & 90 \\
\hline Kepemimpinan Institusional & .6183 & .27982 & 90 \\
\hline Komisaris Independen & .3397 & .10729 & 90 \\
\hline
\end{tabular}

Sumber : Data diolah, 2018

\section{Hasil dan Pembahasan}

Uji asumsi klasik dalam rangka untuk melihat kelayakan model regresi. Hasil uji asumsi klasik menunjukkan bahwa model regresi yang ada telah memenuhi syarat asumsi klasik sehingga model regresi dapat digunakan untuk memperdiksi model yang diajukan. Model regresi berganda yang dikembangkan dalam penelitian ini adalah: DISCLOSED $=0$,858 - 0,20 SIZE $-0,270 \mathrm{KINST}+0,960 \mathrm{KOMIND}+\varepsilon$. Persamaan regresi linier berganda tersebut dapat diartikan bahwa Konstanta sebesar 0,858 menyatakan bahwa jika variabel independen dianggap konstan, maka nilai pengungkapan kebijakan metode transfer pricing (DISCLOSED) sebesar 0,858.

Tabel 2. Coefficients ${ }^{\mathrm{a}}$

\begin{tabular}{|c|c|c|c|c|c|c|c|c|}
\hline \multirow[b]{2}{*}{ Model } & \multirow[b]{2}{*}{ B } & \multicolumn{2}{|c|}{$\begin{array}{l}\text { Unstandardized } \\
\text { Coefficients }\end{array}$} & \multirow[t]{2}{*}{$\begin{array}{c}\text { Standardized } \\
\text { Coefficients }\end{array}$} & \multirow[b]{2}{*}{$\mathrm{t}$} & \multirow[b]{2}{*}{$\begin{array}{c}\text { Sig. } \\
\text { Tolerance }\end{array}$} & \multicolumn{2}{|c|}{ Collinearity Statistics } \\
\hline & & $\begin{array}{l}\text { Std. } \\
\text { Error }\end{array}$ & Beta & & & & VIF & \\
\hline \multirow[t]{4}{*}{1} & (Constant) & .858 & .396 & & 2.168 & .033 & & \\
\hline & Size & -.020 & .024 & -.090 & -.851 & .397 & .932 & 1.073 \\
\hline & $\begin{array}{l}\text { Kepemimpinan } \\
\text { Institusional }\end{array}$ & -.270 & .168 & -.170 & -1.603 & .113 & .925 & 1.081 \\
\hline & $\begin{array}{l}\text { Komisaris } \\
\text { Independen }\end{array}$ & .960 & .429 & .232 & 2.236 & .028 & .967 & 1.034 \\
\hline a. Dep & ent Variable: D & SED & & & & & & \\
\hline
\end{tabular}

Faktor-Faktor yang Mempengaruhi Pengungkapan Kebijakan Metode Transfer Pricing 
Sumber : Data diolah, 2018

\section{Hasil Pengujian Hipotesis \\ Pengaruh Ukuran Perusahaan (SIZE) terhadap DISCLOSED}

Hipotesis pertama, ukuran perusahaan berpengaruh positif terhadap kebijakan metode transfer pricing (DISCLOSED) ditolak. Perusahaan sampel merupakan perusahaan dengan ukuran perusahaan yang cukup beragam, yang ditunjukkan dengan nilai rata-rata sebesar 14,2. Berdasarkan hasil analisis statistik deskriptif, nilai standar deviasi ukuran perusahaan adalah 1,978. Nilai standar deviasi sebesar 1,978 tersebut menunjukkan bahwa titik data cenderung sangat dekat dengan rata-rata. Seteleh dilakukan pengujian dengan analisis regresi berganda, diperoleh nilai koefisien negatif yaitu 0,20 dengan nilai signifikansi sebesar 0,397. Nilai signifikansi sebesar 0,397 yang berada di atas 0,05 menjelaskan bahwa ukuran perusahaan tidak berpengaruh signifikan terhadap kebijakan metode transfer pricing (DISCLOSED). Hasil penelitian ini tidak sesuai dengan teori yang menyatakan bahwa semakin besar ukuran perusahaan, maka semakin besar aset yang dimiliki yang akan mempengaruhi keputusan, termasuk terhadap informasi yang diungkapkan dalam laporan keuangan (pengungkapan metode transfer pricing). Perusahaan sampel tidak memiliki sumber daya yang cukup besar untuk melakukan pengungkapan informasi transfer pricing.

\section{Pengaruh Persentase Komisaris Independen terhadap DISCLOSED}

Berdasarkan hasil statistik deskriptif, dapat diketahui gambaran umum perusahaan sampel, yaitu ratarata persentase komisaris independen dalam perusahaan sampel sebesar 0,3397 dengan nilai terendah 0, 10 dan nilai tertinggi sebesar 0,50. Nilai standar deviasi untuk komisaris independen adalah 0,10 yang berarti bahwa titik data cenderung dekat dengan rata-rata. Nilai tersebut menunjukkan rata-rata perusahaan sampel telah memiliki nilai persentase komisaris independen di atas nilai minimal yang sesuai dengan ketentuan dari OJK, yaitu sebesar 30\%. Setelah dilakukan pengujian dengan melakukan analisis regresi berganda didapatkan nilai koefisien yang positif 0,90 dengan nilai signifikansi di bawah 0,05, yaitu 0,028. Hasil analisis tersebut menunjukkan bahwa persentase komisaris independen berpengaruh signifikan terhadap kebijakan metode transfer pricing. Hasil penelitian ini menunjukkan bahwa hipotesis kedua diterima. Hasil analisis ini konsisten dengan teori yang menyatakan bahwa keberadaan komisaris independen dapat menyeimbangkan keputusan manajer dalam memberikan perlindungan terhadap pemegang saham dan mengurangi konflik agensi. Persentase komisaris independen yang tinggi pada perusahaan sampel menghasilkan pengawasan yang lebih baik terhadap manajemen. Peningkatan persentase komisrais independen ini mempengaruhi kebijakan metode transfer pricing dalam laporan keuangan perusahaan. Hasil penelitian ini sejalan dengan penelitian Karamanou (2005) dan Lo (2011) yang menyatakan bahwa perusahaan dengan persentase komisaris independen yang lebih tinggi akan lebih besar kemungkinanya untuk mengungkapkan secara detail atas transaksi dengan pihak yang memiliki hubungan istimewa.

\section{Pengaruh Kepemilikan Institusional terhadap DISCLOSED}


Berdasarkan hasil statistik deskriptif, dapat diketahui gambaran umum perusahaan sampel, yaitu rata-rata kepemilikan institusional dalam perusahaan sampel sebesar 0,6183. Nilai standar deviasi untuk kepemilikan institusional adalah 0,279 yang berarti bahwa titik data cenderung dekat dengan rata-rata. Nilai tersebut menunjukkan rata-rata perusahaan sampel merupakan perusahaan dengan kepemilikan institusional yang tinggi di atas 50 persen. Setelah dilakukan pengujian dengan melakukan analisis regresi berganda didapatkan nilai koefisien yang negatif 0,270 dengan nilai signifikansi di atas 0,05, yaitu 1,081. Hasil analisis tersebut menunjukkan bahwa kepemilikan institusional tidak berpengaruh signifikan terhadap kebijakan metode transfer pricing. Hasil penelitian ini menunjukkan bahwa hipotesis ketiga ditolak. Hasil analisis ini tidak konsisten dengan teori yang menyatakan bahwa kebeberadaan pemilik institusional dapat menjalankan fungsi pengawasan dan mengarahakan pengambilan keputusan manajemen untuk memberikan perlindungan terhadap pemegang saham institusi, dan mengurangi konflik agensi dengan melakukan pengungkapan informasi metode transfer pricing. Kepemilikan institutional yang tinggi pada perusahaan sampel belum mampu menghasilkan pengawasan yang lebih baik terhadap manajemen dalam praktik pengungkapan metode transfer pricing. Peningkatan persentase kepemilikan institusi ini tidak mempengaruhi kebijakan metode transfer pricing. Hasil temuan ini tidak sejalan dengan riset sebelumnya, yaitu penelitian oleh Karamanou dan Vafeas (2005) dan Lo (2011) yang menyatakan bahwa perusahaan dengan persentase kepemilikan institusional yang lebih tinggi akan lebih besar kemungkinanya untuk mengungkapkan secara detail atas transaksi dengan pihak yang memiliki hubungan istimewa.

\section{KESIMPULAN}

Berdasarkan hasil tersebut, maka dapat diambil kesimpulan bahwa persentase komisaris independen dalam dewan komisaris berpengaruh positif signifikan terhadap pengungkapan kebjakan metode transfer pricing dalam laporan keuangan. Karakteristik perusahaan yaitu ukuran perusahaan tidak berpengaruh signifikan terhadap pengungkapan kebijakan metode transfer pricing dan struktur kepemilikan institusional tidak berpengaruh signifikan terhadap pengungkapan kebjakan metode transfer pricing dalam laporan keuangan. Hal ini menunjukkan bahwa perusahaan yang memiliki ukuran perusahaan yang besar belum mampu melakukan pengungkapan yang tinggi untuk mengungkapkan transaksi pihak berelasi berupa transfer pricing. Kepemilikan institutional dalam perusahaan sampel yang tinggi tidak mampu mengarahakan praktik penungkapan metode transfer pricing . Keberadaan Komisaris Independen dalam perusahaan sampel dapat menjalankan fungsi pengawasan dan mengarahkan pada praktik pengungkapan informasi secara penuh melalui laboran keuangna, yaitu pengungkapan kebijakan metode transfer pricing.

Keterbatasan dalam penelitian ini, adalah tahun pengamatan belum memasukkan periode pasca implementasi IFRS, yaitu tahun 2012, sehingga belum dapat menjelaskan secara lebih jauh perbedaan pengungkapan transaksi pihak berelasi dalam hal tranfer pricing sebelum implementasi dan setelah implementasi IFRS. Penelitian ini hanya meneliti struktur kepemilikan institusional, dan belum memasukkan konsentrasi kepemilikan keluarga dan pemerintah, sehingga belum dapat melihat pengaruh jenis struktur kepemilikan lainya terhadap pengungkapan kebijakan metade transfer pricing. 


\section{DAFTAR PUSTAKA}

A.Zahra, S., :Priem, R., \& A.Rasheed, A. (2005). The Attecedents amd Consequences of Top Mangement Fraud. Journal Of Management.

Adolf A, B. J., \& C.Means, G. (1932). Modern Corporation and Private Property. Mac,illan Company.

Ajinkya. (2005). The Association between Outside Directors, Institutional Investor and The Properties of Management Earnings Forecast. Journal Of Accountancy Research.

Almilia, L. S. (2008). Faktor-faktor yang Mempengaruhi Pengungkapan Sukarela Internet Financial and Sustainaibility reporting. JAAI, 117.

Boyns, T., Edward, J. R., \& Emmanuel, C. (1999). Determinants Of The Transfer Pricing Change. Managment Accounting Research, 85-108.

E.Verrecchia, R. (1983). Discretionary Disclosure. Journal Of Accounting and Economics, volume 5 page 179194.

Eng, L., \& Mak, Y. (2003). Corporate Governance and Voluntary Disclosure. Journal OF Accountancy and Public Policy, 325-345.

F.Gox, R. (2000). Strategic Transfer Pricing. Management Accounting Research.

Fauzi, H., S.Mahoney, L., \& Rahman, A. A. (2007). The Link Between Corporate Social Performance and Financial Performance: Evidence From Indonesian Companies. Social and Environmental Accounting, 149-159.

Gordon, J. (2004). European Journal Of Education.

Healy, P. M. (1999). A Review Of the Earnings Management Literature and its Implication For Standard Setting. SRRN, 36.

Jensen, M. C., \& Meckling. (1976). ost and Ownership StructureTheory Of The firm :Managerial Behavior,Agency Cst. Journal Of Financial Economics.

K.Chaua, G., \& J.Gray, S. (2002). Ownership Stucture and Corporate Voluntary disclosure in Hongkong and Singapore. International Journal Of Accountancy.

Karamanou, I., \& Vafeas, N. (2005). The Association Between Corporate Boards, Audit Comittees, and Management Earnings Forecast: An Empirical Analysis. Journal Of Accountancy Research.

Kohlbeck, M. J., \& W.Mayhew, B. (2004). Related Party Transaction. FARS Meeting Paper. Florida.

Kurniawati, M., \& Yaya, R. (2017). Pengaruh Mekanisme Corporate Governance, KInerja Keuangan, dan Kinerja Lingkungan terhadap Penungkapan Islamic Social Reporting. Journal Of Accounting and Invesment.

M.Eisenhardt, K. (1989). Agency Theory:An Assesment and Review.

Machmud, N., \& D.Djakman, C. (2008). Pengaruh Struktur Kepemilikan terhadap Luas Pengungkapan Tanggung Jawab Sosial (CSR disclosure) pada Laporan Tahunan Perusahaan :Studi Empiris Pada Perusahaan Publik Yang Terdaftar di Bursa Efek Indonesia tahun 2006.

Novitasari, T., \& Indira, J. (2009). Pengaruh Struktur Kepemilikan Terhadap Kinerja Intelctual capital . Junral Akuntansi dan Auditing.

Putri, I. F., \& Nasir, M. (2006). Analisis Persamaan Simultan Kepemilikan Manajerial, Kepemilikan Institusional. 
Resiko Kebijakan Hutang dan Kebijakan Devidrn Dalam Perspektif Teori Keagenan. Jurnal Ekonomi, Manajemen dan Akuntansi.

R.Graham, J., Harvey, C., \& Rajgopal, S. (2005). The Economic Implication Of Corporate Financial Reporting. Journal Of Accountancy and Economics, 3-37.

Simamora, H. (1999). Akuntansi Manajemen. Jakarta: Salemba Empat.

Sugiri, S. (2005). Kejujuran Management Sebagai Dasar Pelaporan Laba Berkualitas. Pidato Pengukuhan Jabatan Guru Besar Fakultas Ekonomi Universitas Gajah Mada.

Suijs, J. (2005). Voluntary Disclosure Of Bad News. Journal Of Business Finance and Accounting.

Talha, M., Alam, S. S., \& Sallehhuddin, A. (2005). Trandfer Pricing And Taxation Implication Disclosure im Segmental Reporting :malaysian Evidence. International Business and Economic Research Journal.

Thomas, M. (2011). Transfer Pricing For Coordination and Profit Allocation. Australian Journal Of Business and Magement Research.

TJ.Wong, \& Jian, M. (2003). Earning Management and Tunelling Through Related Party Transaction:Evidence From Chinese Corporate Groups. EFA, (p. 48). China.

Vernon J.Richardson. (1998). Information Asymetry and Earnings Management :Some Evidence. University Of Arkansas Fayetteville.

Xie, B., Davidson, W. I., \& Dadalt, P. J. (2003). Earnings Mangement and Corporate governance: The Role of Board and the audit committe. Journal Of Corporate Finance, 259-316. 
